\title{
Construction of rape culture amongst the Shona indigenous religion and culture: Perspectives from African feminist cultural hermeneutics
}

\begin{tabular}{|c|c|}
\hline \multicolumn{2}{|c|}{$\begin{array}{l}\text { Authors: } \\
\text { Nomatter Sande }^{1} \\
\text { Sophia Chirongoma }^{1}\end{array}$} \\
\hline \multicolumn{2}{|c|}{$\begin{array}{l}\text { Affiliations: } \\
{ }^{1} \text { Research Institute for } \\
\text { Theology and Religion (RITR), } \\
\text { College of Human Sciences, } \\
\text { University of South Africa, } \\
\text { Pretoria, South Africa }\end{array}$} \\
\hline \multicolumn{2}{|c|}{$\begin{array}{l}\text { Corresponding author: } \\
\text { Nomatter Sande, } \\
\text { pastornomsande@yahoo.com }\end{array}$} \\
\hline \multicolumn{2}{|c|}{$\begin{array}{l}\text { Dates: } \\
\text { Received: } 14 \text { Mar. } 2021 \\
\text { Accepted: } 05 \text { July } 2021 \\
\text { Published: } 27 \text { Aug. } 2021\end{array}$} \\
\hline \multicolumn{2}{|c|}{$\begin{array}{l}\text { How to cite this article: } \\
\text { Sande, N. \& Chirongoma, S., } \\
2021 \text {, 'Construction of rape } \\
\text { culture amongst the Shona } \\
\text { indigenous religion and } \\
\text { culture: Perspectives from } \\
\text { African feminist cultural } \\
\text { hermeneutics', HTS } \\
\text { Teologiese Studies/ } \\
\text { Theological Studies } \\
77(2) \text {, a6619. https://doi. } \\
\text { org/10.4102/hts.v77i2.6619 }\end{array}$} \\
\hline \multicolumn{2}{|c|}{$\begin{array}{l}\text { Copyright: } \\
\text { (C) 2021. The Authors } \\
\text { Licensee: AOSIS. This } \\
\text { is licensed under the } \\
\text { Creative Commons } \\
\text { Attribution License. }\end{array}$} \\
\hline \multicolumn{2}{|l|}{ Read online: } \\
\hline 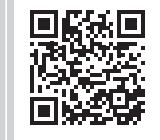 & $\begin{array}{l}\text { Scan this QR } \\
\text { code with your } \\
\text { smart phone or } \\
\text { mobile device } \\
\text { to read online. }\end{array}$ \\
\hline
\end{tabular}

Rape culture is reportedly prevalent in sub-Saharan Africa. Culture, patriarchy, poverty and religion continue to sustain rape culture. The notions of the objectification of women's bodies amongst the Shona people are causatives for rape culture within diverse cultural institutions. Africans reasonably uphold marriage with high esteem; unfortunately, the marriage institution is also susceptible to becoming a source of abuse, coercion, and is often used as a tool for controlling women. Some of the entrenched marital rituals embody diverse detrimental and contentious practices, which deprive girls and women their autonomous rights, particularly their sexual and reproductive rights. This research article interrogates numerous aspects within the Shona indigenous religion and culture, which precipitate the construction of rape culture. The study uses African feminism as a theoretical framework. It utilises African feminist cultural hermeneutics to interrogate rape culture amongst the Shona people. The research study is qualitative with a conceptual analysis paradigm. It concludes by proposing the need for tapping into some life-giving and gender inclusive principles within the Shona indigenous religion and culture to be utilised as tools for eradicating rape culture.

Contribution: Utilising the African feminist cultural hermeneutical framework, the article interrogated several factors precipitating rape culture amongst the Shona people. It foregrounded that women bear the brunt of burden of rape culture. It concludes by proposing the need for tapping into some positive Shona indigenous traditions as tools for curbing rape culture.

Keywords: African feminist cultural hermeneutics; marriage; rape culture; Shona indigenous religion; Zimbabwe.

\section{Introduction}

With particular reference to the indigenous Shona people in Zimbabwe, this research study presents the intersectionality between the gender oppressive norms embedded in African indigenous religion and culture, which have the propensity for perpetuating rape culture in subSaharan Africa (Ackermann 2004; Brown 2018; Nadar 2006; Petrus 2017). Our use of the terms African indigenous religion and culture leans on the definitions of these terms brought forward by scholars, such as Olupona (2007:15), who articulates that 'traditional African religions refer to the indigenous religious beliefs and practices of the people of Africa that includes worship, consultation of priests, rituals, symbols, cosmology, arts, practices, society'. In the same light, Mbiti (1970:12) explained that 'traditional African religion is part and parcel of culture in Africa'. Tamale (2013:2) also averred that 'African traditional religions cannot be delinked from culture'. Similarly, Beyers (2017:1) explicated that 'in Africa, religion is a custodian of culture'. Hence, our discussion in this article makes reference to these terms in an intertwined manner to reflect the fact that:

[T] here is an inescapable embeddedness of traditional African religions in people's ways of thinking and knowing to a point that it is nearly impossible to extricate oneself from it without strong feelings of stripping off a major part of one's cultural identity. (Ndemanu 2018:71)

We make the contention against this background that the Shona indigenous religion and culture are intricately interlinked. This research article therefore argues that rape culture is a social construct subtly sustained through religious practices amongst the Shona people. The challenge

Note: Special Collection: Women Theologies, sub-edited by Sinenhlanhla S. Chisale (Midlands State University) and Tanya van Wyk (University of Pretoria). 
that emerges from this status quo is that the Shona indigenous religion and culture view gender issues as relational ontology.

It is also important to explain, using the umbrella terms 'Shona indigenous culture and traditions', that there are several sub-groups of the Shona, including the Karanga, Zezuru and Korekore. However, these Shona sub-groups share numerous similarities when it comes to their gender perspectives, as well as religious traditions and practices. One of the common grounds uniting the Shona people is their patriarchal structure, which tends to privilege men whilst disadvantaging women. Hence, in the discussion of rape culture amongst the Shona in this article, we are referring to the unity and diversity amongst the Shona sub-groups because their gender dimensions are interwoven. For instance, the picture that is commonly painted is that:

$[M]$ en and women had well-defined roles and obligations that were specific and exclusive to their respective genders. The division of labour was such that the domestic sphere, on the one hand, belonged to the woman, and there her authority was unchallenged; the public domain, on the other hand, belonged to the man. Neither arena was regarded as superior to the other. (Owomoyela 2002:91-92)

The portrayal of this purportedly gender equitable picture makes the Shona indigenous religion and culture susceptible to hatching negative traits like rape culture, which society is not yet ready to confront. The pervasiveness of rape culture is precipitated by the fact that it is woven within people's worldviews, norms and practices, which inadvertently affects their day-to-day lives. So, to follow Owomoyela's argument that the well-defined roles between men and women were regarded equal and none was superior to the other is like turning a blind eye to the dynamics of the social construction of gender roles. It is becoming evident that patriarchy is the primary causative factor for the challenges, which bedevil women within the African traditional religion and culture. Second to patriarchy is the marriage institution, which is highly esteemed but oppresses women. According to Togarasei (2012), marital rituals like roora (bride price) have the propensity of reducing women to mere commodities up for grabs. In the Shona indigenous religion and culture, rape culture is embedded in the patriarchal and hierarchical structures, which elevate boys and men to a higher pedestal, whilst women and girls are pushed to the bottom rung of the societal ladder. In light of this background, the primary aim of this study was to interrogate how religio-cultural practices construct rape culture amongst the indigenous Shona people in Zimbabwe.

There has been a steady increase in the literature focusing on women's experiences and gender issues, in general (Ademiluka 2018; Arnfred 2004; Chireshe 2015; Kambarami 2000; Manyonganise 2015). This has immensely contributed towards dismantling vices that affect women. Whilst the interface between religion, genders, and sexualities has, and continue to, receive attention in sub-Saharan Africa, there is a need for complementing this by addressing how the Shona indigenous religion and culture promote rape culture.
Besides identifying several factors that affect women in the Shona indigenous religion and culture, more work needs to be carried out to unearth these problems' social constructions. For instance, it is evident that rape culture is prevalent in sub-Saharan Africa, but there is a gap on the literature, which explores how this culture is socially constructed amongst the Shona people (Arnfred 2004; Brown 2018; Petrus 2017). Sociologists argue that how people are brought up contributes to the formation of their behaviour. As noted by Buchwald, Fletcher and Roth (2005:xi), rape culture is defined as 'a complex set of beliefs that encourages male sexual aggression and supports violence against women'. In this article, we resonate with the views raised by UN Women (2019) who affirm that the overarching challenge with rape culture is that it affects everyone 'regardless of gender identity, sexuality, economic status, race, religion or age'.

\section{Theoretical framework}

This study uses the African feminist theory in an endeavour to unpack how some of the prevalent traditions and practices construct rape culture within the Shona indigenous religion and culture. As expounded by Oyekan (2014:1), African feminism is a theoretical perspective, which contends that 'there are peculiar conditions in Africa which raise unique challenges for the feminine gender'. Whilst affirming the global continuities in the women's struggles, the African feminist theory affirms that gender justice and gender equality will remain a pipedream if advocates for these values fail to pay attention to the specific cultural and religious traditions that shape African people's worldviews (see Ahikire 2014; Bayu 2019; Manyonganise 2015). In essence, the African feminist theory emphasises the fact that understanding and effectively addressing African women's struggles can be best achieved by firstly comprehending their contextual realities. The main tenets of African feminism are relevant for this study because they provide a lens for discussing the African gender relationships within African ontological and epistemological underpinnings. Adopting the African feminist theory is an important step towards unearthing the religio-cultural underpinnings within the Shona people's views on male and female sexual and reproductive rights. This is in accordance with the 2006 Charter of Feminist Principles for African Feminists, which foregrounds the following points:

By naming ourselves as feminists we politicise the struggle for women's rights, we question the legitimacy of the structures that keep women subjugated, and we develop tools for transformatory analysis and action. We have multiple and varied identities as African feminists. We are African women - we live here in Africa and even when we live elsewhere, our focus is on the lives of African women on the continent. Our feminist identity is not qualified with 'ifs', 'buts' or 'howevers'. We are Feminists. Full stop. (cited from Ahikire 2014:1)

Therefore, this study taps into the African feminist cultural hermeneutical framework in order to interrogate the Shona indigenous practices and values guiding the relationships between men and women, which perpetuate rape 
culture within the broader community. Simply put, the starting point to understand how rape culture is constructed within the Shona indigenous religion and culture is by examining aspects, such as culture, economics, psychology, health and religion and Indigenous Knowledge Systems. Concurring with the African feminist cultural hermeneutics' standpoint on the multiple dimensions of African women's experiences, this study illustrates how some of the entrenched indigenous Shona practices provide a fertile ground for rape culture in our contemporary society. Henceforth, we argue that as the practices and values happen in a socio-cultural context, they are constructed. It therefore follows that the manner in which rape culture is perpetuated is not universal but uniquely peculiar to a particular context (Kanyoro 2002). One of the major proponents for utilising the African feminist cultural hermeneutical framework is Kanyoro (2002), who enunciated its utility in the following way:

If today African women are able to name the oppressive aspects of African cultures, it has not come easily. Telling these stories of dehumanizing cultural practices is still rare and a struggle... The question confronting women theologians in Africa is how can discussions on culture be incorporated in our communities so that women find it safe to speak about issues that harm their wellbeing?... African women theologians who have encountered feminist analysis do not quickly jump to condemn women for being custodians of dehumanizing cultural practices. It is realized that even women's actions are too deeply rooted in patriarchal socialization and therefore the analysis of women's oppression has to be done in the context of gender analysis. We need to look and see how our societies are organized and how power is used by different groups, men and women, young and old, people of varying economic means, and so on. Who benefits from a particular interpretation of culture and how is the system kept in place? (p. 17)

Following in Kanyoro's footsteps as explained above, this article adopts a gender analysis, it also engages in a hermeneutics of interpreting the Shona indigenous beliefs and traditions, which provide fecund ground for rape culture. Kanyoro (2002) explained this process in the following way:

Gender analysis takes into account ways in which roles, attitudes, values and relationships regarding women and men are constructed by all societies all over the world. The concepts and practices of equality and discrimination determined by social, economic, religious and cultural factors lie at the heart of gendersensitive perspectives. Theological engagement with gender issues seeks to expose harm and injustices that are in society and are extended to Scripture and practices of the Church through culture...The fact that gender roles differ significantly from one society to another and from one historical period to another, is an indication that they are socially and culturally constructed. (p. 17)

It is against such a background that this study examines gender attitudes and sexual violence-supportive beliefs (rape myths) amongst the indigenous Shona people.

\section{Understanding rape culture}

Rape culture is a global phenomenon, manifesting in diverse forms. Additionally, rape culture is an elusive concept, and it is critical to explain what it is. By definition, rape culture is the normalisation of sexual assault. A proper definition of rape culture emerged around 1970. The first scholar to define rape culture was Herman (1984), who argued that as long as male dominance is celebrated in society, rape will be pervasive. Rape culture is evident whenever a rape is as clear as death (Buchwald, Fletcher \& Roth 1994). Rape culture does not only manifest when women are raped but also cover a broad spectrum, such as men, as well as the lesbian, gay, bisexual, transgender, queer and intersex (LGBTQI) communities being exposed to sexual violence (Ridgway 2014). From Ridgway's assertion, it is correct to conclude that rape culture is an intersectionality phenomenon bringing to the table issues of gender, race, ethnicity, sexuality, disabilities and so on. Brown (2018) further argues that:

The origins of male sexual aggression are seen as one of the main connecting factors between rape of all nations... demonizing victims, diminishing the seriousness of the crime, and sexualizing and normalizing sex and rape within the media. (p. 13)

The views raised by the scholars cited above foreground the fact that rape culture is precipitated by trivialising the sexual violence perpetrated on the victims.

The statistics about rape culture differ across the world. However, what is certain is that rape culture is promoted by many factors, which include, but are not limited to, hegemonic masculinity, rape myths and language. According to Kivel (2012), the problem of rape culture is that regardless of where one lives, there is a dominant teaching that men should take a leading and dominating role, as well as exercise their position of power and authority by engaging in sexual aggression. Accordingly, most men aspire to follow and conform to such a path. More so, in the contemporary world, social media sustains hegemonic masculinities and men are portrayed as aggressive creatures. Maxwell (2014) argued that the media objectifies women's bodies. Like culture, musical lyrics, especially popular music, reinforce rape culture (Ridgway 2014). As articulated by Najumi (2013), the misogynistic language was used as a vehicle to foster rape culture. The language was also used in a teasing or in a jocular manner. Furthermore, rape culture is portrayed through rape myths. The role of rape myths is to blame the victims. Some examples of rape myths were propounded by Burnett et al. (2009), who, through his research on the role of communication, found statements like women say 'no' when they mean 'yes' or 'only promiscuous women get raped', or 'women falsify their rape' and often times, the victim gets blamed for getting raped because of 'what she was wearing', which aroused the rapist. When discussing rape culture, especially within the context of heterosexual relationships, it is paramount to highlight the fact that the penis is often used as a tool of rape. This is important because it reveals that rape culture goes deeper than just sexual coercion. It also helps in conceptualising how the penis is constructed and understood in our cultural and religious spaces. Adeniyi (2021) puts this succinctly: 
Since the dawn of time, rape and sexual violence against women has remained a thorny issue that defies every approach to stamp it out of society ... One of the manifestations of the drift is the trivialization or normalization of rape cases and male sexualized violence in many rape cultures ... As one of the most commonest forms of gender-based offenses committed against women, rape is believed to be a patriarchal weapon of women's suppression and a mechanism for sustaining gender stratification in male dominated societies. Rape is a means of expressing masculinity and an act by which men are allowed to punish or threaten women ... (p. 1)

Butler (1993) also provides a useful analysis of rape culture; she argues that heterosexuality creates sexual differences that construct the gendered heterosexual body with regards to the penetrator and the penetrated where the one with a penis is the penetrator and the one with a vagina is the penetrated. The same viewpoints are raised by NgubaneMokiwa and Chisale (2019) who argued that:

The 'most common' sexual penetration among the heterosexual is culturally and religiously constructed as the penetrator who is regarded as the powerful on top and the penetrated and powerless under. (p. 109)

Another impediment in eliminating rape culture in most patriarchal societies is the marriage institution whereby married women who are raped by their spouses find it difficult to raise an alarm (Khau 2007). Concurring with the above views, we also aver with Brownmiller (1975:292) who stated that 'male victims of rape are not neglected or actively "forgotten," although female victims take precedence'. It is therefore apparent that there are a myriad of factors that endorse the normalisation of rape culture in most communities. In the next section, we proceed to discuss the Shona indigenous practices, which serve as a launchpad for the construction of rape culture.

\section{Shona indigenous practices precipitating the constructions of rape culture}

Using the Shona people as a case study, this section deliberates on some of the indigenous practices, which often serve as incubators of rape culture in Zimbabwe. Notions of gender equality, equal rights, property rights, control and pre-marital sexual conducts are factors that led to rape culture.

\section{Roora (bride price) and the marriage institution}

The concept of roora is a critical element accepted by society, culture and religion. The roora concept is praised, and many people continue to embrace the practice; however, it would be naïve not to look at its downside. The patriarchal cultural lenses of Shona society have led people not to dismiss the hefty bride price, which commodifies women. Hefty bride prices foster the idea that women are there to serve men. In tracing the historical development of the roora tradition, it becomes apparent that the prospective groom would give something valuable like a hoe for farming to his prospective bride's father. However, in the contemporary society, roora has been converted into cash (Chiweshe 2016:229, 235). If not clearly enlightened about this practice, paying roora subconsciously creates the thinking that one is buying something. Hence, paying roora constructs a masculine attribute, resulting in men boasting that he has got the ability to materially provide for all his wife's needs.

To some extent, charging roora is determined by the girl's education and employment status. Clearly, this becomes an initial step towards the commodification of female bodies, which consequently creates fecund ground for the consumer culture. In the light of this background, women will be treated as the 'goods', and the men will be 'the buyers' and 'the seller'. In some cases, once the man has paid roora, he begins to have a misplaced sense of entitlement whereby he feels that he 'bought' his wife's sexuality. As such, he tends to behave as if the wife should avail her body for sex as and when he so desires. As Togarasei (2012:53) puts it across, 'the husband and his family purchase the woman in her totality, including her domestic labour and children'. If Togarasei's (2012:53) assertion is anything to go by, roora makes women powerless, inferior and weak. Rape culture thrives when male predators view women as vulnerable. Such a status quo precipitates the sexual abuse of women in the marital institution.

Unequal gender relations in marriage are another major source for the construction of rape culture. Muguti and Sande (2019) critiqued some of the teachings inherent in the Shona indigenous religion and culture which promote women's sexual objectification. For instance, the premarital counselling availed by elderly women, such as vana vatete (aunts) and vana mbuya (grandmothers), reiterating the fact that the proper behaviour for a married woman is to restrain herself from making any sexual advances on her spouse, as well as regurgitating the fact that she must focus on sexually satisfying her husband whilst sacrificing her own sexual needs. Such 'counsel' from the matriarchs practically denies the married woman any opportunity of enjoying conjugal rights. In essence, these teachings turn married women into objects designed to fulfil their spouses' sexual satisfaction whilst depriving them of the power to negotiate for safer sex. These indigenous practices also take away the married woman's sexual autonomy (Chirongoma 2016). Accordingly, Brown (2014) proffered that if accorded their autonomous sexual and reproductive rights, women will be empowered to decide whether, when, how and with whom to have sexual intercourse. Thus, the marital institution should be defined by sexual autonomy. This coheres with Moradi (2008) who stated that:

[S]exual objectification occurs when a woman's sexual parts or functions are separated out from her person, reduced to the status of mere instruments, or else regarded as if they were capable of representing her. To be dealt with in this way is to have one's entire being identified with the body. (p. 377)

From a younger age, girls are socialised to uphold the fact that their main goal should be that of fulfilling their husband's 
needs, particularly to ensure that he is sexually satisfied (Perrin et al. 2019). Even as grown-up women, their bodies are expected to be in specific body shapes and they should maintain a specific skin colour (Crenshaw 1991). In the contemporary society, this often exerts undue pressure on some women to maintain a slim figure and a flat tummy, as well as use skin lightening creams so as to transform into a sexy slay queen who is slender and a 'yellow bone' (light skinned) (Thompson 2008). However, men conceived that women are at their disposal and that it is the woman's responsibility to ensure that there is marital bliss by maintaining an attractive figure whilst performing everything possible to make sex enjoyable for the man (Wood 1994). This mentality enhances rape culture because from a tender age, men are made to believe that they can control women in all areas, including issues to do with intimacy.

The bedrooms are regarded as a private and sacred place. Hence, anything said or performed in the bedroom is hardly questioned. This breeds fertile ground for marital rape. Some married men are notorious for behaving like bedroom bullies. Countless married women do not have any freedom in their bedrooms, and it is regrettable that many rape cases happen in this space. There is a general assumption that married women cannot be raped (Khau 2007). Because of the heavy lid of secrecy shrouding the subject of marital sex within the indigenous Shona communities, some married women have never been given room to talk about how they feel regarding the sexual encounters with their spouses. The Shona patriarchal traditions and culture accord married men an upper hand when it comes to individual rights and freedom of sexual expression (Chitando 2015).

\section{Veiling infertility in a marital union}

Infertility is a factor that can also trigger rape culture within marriage. According to Sande and Takawira-Matwaya (forthcoming), infertility not only is dreaded in Zimbabwean society but also has resulted in many broken marriages and estranged relations between in-laws. Therefore, families come up with a solution to deal with the issue of infertility. The only problem is that infertility is a gendered phenomenon; women are primarily held responsible for infertility (Oduyoye 2004). Accordingly, to protect the men's ego and masculinity, the practice of kupindira [young brother or nephew having sexual intercourse with the affected man's wife in order to sire children] is often used. Chingombe, Mandova and Nenji (2012) noted that it is culturally taboo to publicise a man's infertility or weakness because the autocratic and patriarchal nature of the Shona culture is intent on protecting and perpetuating masculine chauvinistic tendencies. Thus, kupindira practice was customarily arranged by close family members, and the woman is rarely given an opportunity to make any decision pertaining to this arrangement. In cases where the wife may have choices, the problem was that infertility would warrant divorce or barika [polygamy], thereby putting pressure on the woman to accept the arrangement. Hence, in trying to conceal the man's infertility, his wife is forced to engage in sexual intercourse with her husband's close male relative, and if she falls pregnant, she will be expected to pretend that the children belong to her husband. Clearly, this is an arranged form of rape whereby the woman is coerced to keep these clandestine sexual encounters a secret from her husband.

In the event of infertility in wives, the Shona culture encouraged a marital custom called chigadzamapfiwa [substitute wife] or barika [polygamy] to make sure that there are children born (Chigidi 2009). Whilst these practices could promote the broader society, a close analysis shows that women had a lot to lose because the young girl who is usually the younger sister or niece to the infertile woman is often forced to become chigadzamapfiwa. Usually, she would be instructed to visit either her sister or aunt and during her visit, the uncle or brother-in law would either persuade or coerce her to engage in sexual intercourse with him. The coerced sexual intercourse would seal the deal of her becoming the substitute wife. This is tantamount to rape because the young woman will have little or no say in the matter.

\section{'Corrective rape' perpetrated against the lesbians, gays, bisexual, transgender, queer and intersex communities}

It is equally pertinent to redress the fact that because of the predominantly heteronormative stance within most indigenous African communities, likewise, amongst the Shona people, sexual orientations like the LGBTQI communities are regarded as a misnomer. As a result, the myopic masculine power often results in some overzealous men forcing members of the LGBTQI to conform to certain sexual and gender stereotypes, which is regarded as a form of 'corrective rape culture' (Doan-Minh 2019). Similarly, disability status is contested mainly within the African indigenous tradition and culture, increasing women's vulnerability. According to statistics, about $80 \%$ of persons with disabilities, particularly women, are raped (Madden 2014).

\section{Chiramu (sanctioned teasing or flirting)}

The practice of chiramu is another source of rape culture, where a married man engages in sanctioned teasing or flirtations with his wife's younger sister or niece. Whilst this is intended to be sanctioned teasing to foment relationships amongst in-laws, regrettably, some men tend to overdo it to such an extent that they end up raping the wife's sister or niece, which are hardly reported. The perpetrators use the gender skewed societal norms and values to escape their crimes. In such cases, it becomes difficult for the young woman who has been violated to report the rape case because what would have started as a joke would have turned nasty. Often times, the Shona indigenous communities legitimise such acts of sexual violence by either forcing the man to marry the victim as she would already be culturally considered as his 'wife' by virtue of being his wife's sister or niece. If the man is unwilling to marry the rape victim or the 
victim refuses to become the perpetrators' wife, then he is required to pay compensation to the victim's family. The compensation is generally referred to as 'damage' because the young woman who would have been sexually violated will be treated as 'damaged goods', denoting the loss of her virginity (Chirongoma 2006).

At times, Shona society treats rape cases as myths in a bid to evade having to deal with the harsh reality of these crimes. Burt (1980:217) argued that rape myths are 'attitudes such as sex role stereotyping, adversarial sexual beliefs, sexual conservatism, and acceptance of interpersonal violence'. Rape myths revolve around the notions that 'women invite it' and 'rapists are sex-starved, insane, or both'. Therefore, victim blaming is an attitude that the perpetrators use to avoid taking the responsibility for their crime (Fakunmoju et al. 2021). Other specific statements, such as 'they asked for it', 'it was not rape', 'they did not mean to' and 'they liked it,' are also used to justify the sexual violence (Petrus 2017). In some cases where the perpetrators come close to admit their actions, they often hide behind the finger by painting women as hure, joki or pfambi [slut, bitch or prostitute]. Objectifying women by calling them names normalises violence against women. Such statements are common beliefs propagated within African indigenous communities to reinforce blame towards the victim. It is therefore pertinent to accept that rape-affirming notions are entrenched in the language we use daily. The ensuing section deliberates on the issues of language entrenching rape culture amongst the indigenous Shona communities.

\section{Manipulation of Shona proverbs, myths and idioms}

As language is embedded in culture, the words and phrases used have the power to shape reality. The masculine sexual language used to describe men often promotes bullying women and licenses them, including the married men to engage in sex with multiple partners. For instance, men are often described as bhuru [bull], which is not limited to one heifer, or murume ijongwe [the man behaves like a cock]. Personifying masculine behaviour to the metaphor of a bull denotes that just like a bull cannot be controlled but moves from one kraal to the other, therefore, a man also has an insatiable sexual appetite, such that he hops from sleeping with one woman to the next. Similarly, as a fowl run with more than 50 hens can be fertilised by only one cock, one man can impregnate several women. These descriptions present the picture that men exist to satisfy their sexual ego with anyone they can think about. The use of language makes rape culture elusive. How the society describes men through masculine lenses sustains power over women. Sexual violence, in this case, is normalised and justified because people are made to accept any irresponsible sexual behaviour on the part of man as being the way men were created. However, in this article, we concur with Lonsway and Fitzgerald (1994) who argue that rape myths are false, they are simply intended to rationalise masculine sexual permissiveness and violence perpetrated against women. Buying masculinity ideas subtly makes 'violence and dominance' as symbols of 'strength', making girls and women less important and valueless; such a mind-set continues to promote rape culture.

The enshrined Shona wisdom sayings and proverbs are another bedrock for rape culture. One of these includes the concept of swearing to secrecy couched in its antonym kufukura hapwa [do not wash your dirty linen in public]. This is a teaching emphasised especially to the girl child from a very tender age. According to this teaching, family secrets of ills, failures and taboos are not supposed to be revealed to the public. Hence, anything bad which happens in the family must be kept confidential (Chirongoma 2006). The problem of kufukura hapwa is that it makes rape appear like a 'myth'. As a result, some women fear kufukura hapwa and deny personal vulnerability to rape. What is even more heart wrenching is the harsh reality of the fact that the ingrained patriarchal culture 'recruits' other women to become accomplices to this 'secrecy cult' such that they will not defend their fellow women when they get raped by family members or relatives. Instead of showing solidarity with their fellow women who would have become victims of rape, they further victimise them by either making them feel guilty of inviting the rape or they simply shush the victims into silence. As such, rape culture weighs heavily on the survivors because it silences them even if they wish to either share their narrative or to demand justice against all odds. This environment breeds a victim-blaming culture whereby sufferers and survivors of sexual and gender-based violence are made to feel that they either did something or they failed to do something to protect themselves from the violations that were perpetrated against them (Mungwini \& Matereke 2010). Consequently, the kufukura hapwa ideology makes many family members accomplices to the crime. Another closely related 'secrecy cult' ideology amongst the Shona people is embedded in the proverb chakafukidza dzimba matenga [what happens in the confines of the domestic sphere should not be unveiled for public consumption] (Chirongoma 2006). Whilst the original intent of this proverb was to maintain a considerable level of decency and confidentiality in the domestic sphere, it has unfortunately been oft manipulated to trap women who suffer from domestic violence, including marital rape or incest to remain ensnared and mummed into silence. Likewise, Muguti and Sande (2019:186) are of the opinion that the abuse of 'the Shona proverb, chakafukidza dzimba matenga (what covers the houses is the roof) meaning that there are unrevealed secrets, challenges and happiness which should remain confined within the domestic realm' is guilty of disempowering women. In the context of rape, the abuse of this proverb perpetuates the alienation of survivors, and this inhibits their chances to speak out or to take legal action against the perpetrator because they will be afraid of being further victimised by the society for revealing the family secrets (Chiroro et al. 2004).

The African traditional religion and culture have a way of maintaining the status quo within families. Often, whenever there are incidences of sexual violence, particularly if it is 
marital rape, the counsel given to women enduring such violations is summed up in the Shona statement, ndozvinoita mudzimba (these are some of the struggles you ought to endure as a family-oriented person). Such cultural counsel or advice reaffirms the fact that ndozvinoita mudzimba neglects the trauma related to rape, nor does it make the experience less severe or bearable. It is our contention that instead of sweeping the incidences of rape under the carpet using the blanket response, ndozvinoita mudzimba, the Shona people must be proactive in redressing these violations on the women's humanity and dignity. They must create safe spaces within the indigenous communities where women can relate their experiences of trauma and be assured that their pain and victimisation are not trivialised.

\section{Gender skewed communal justice systems}

The Shona communal justice system also has the propensity of facilitating rape culture. This is because of the fact that amongst the Shona community, just like most of the African indigenous communities, the justice systems are male dominated. Often times, these justice systems permeate the political and social realms. The problem with this connection is that it cements traditionally negative and harmful perspectives, which ascribe restrictive and unequal gender roles for women and girls in society. As a result of these inherent gender disparities in the justice system, there are numerous religious traditions, beliefs and ethos, which either sustain or condone the abuse of women. Resultantly, most religious leaders and powerful men in society elusively get away with rape. There is therefore an urgent need for revisiting the Shona culture so as to unearth the gender identities and social justice policies, which can be used to redress rape culture. At one point, Manyonganise (2015) suggested the use of the Shona idiom musha mukadzi [the woman or wife is the anchor of the home], showing how women's space is created. However, in the context of rape culture, such proverbial phrases like musha mukadzi pacify women and prevent them from coming out and speaking about the social injustices they face at home.

\section{Towards redressing rape culture}

It is evident from the above discussion that some Shona indigenous practices provide a springboard for the construction of rape culture, which is hidden and subtly operates within the religious circle. The question remains as to what structures within the Shona indigenous practices are available to facilitate the eradication of rape culture. This article proposes the use of the principles of ukama [kinship], hunhuism [humanness/human kindness] and the sanctity of life as tools that can help to stand against rape culture.

\section{Ukama (kinship)}

The principle of $u k a m a$ [kinship] controls social relationships and determines individuals' behaviour towards others within the Shona indigenous religion and culture (Murove 2007). As rape culture is enhanced by the way people think and speak, kinship shows that all people are descendants of a common ancestor, making people connected. Such an ideology helps people to respect one another, and hence, it can be utilised as a formidable tool to curb the sexual abuse and violence within the Shona indigenous religion and culture. So, women deserve autonomy in their lives and bodies. This echoes the views raised by Sande (2017:50) reaffirming the fact that the concept of equality between sexes is the most appealing and influential for appraising social structures'. In the same light, Jewkes et al. (2013) propound that the best way to solve rape culture is to ensure that there is an early education on male role socialisation. Emphasising kinship helps to weaken or uproot the patriarchal mentality, which gives men the power to control women (Chitando 2008). Within the marital sexual space, men should be trained not only to hear but also to listen when women say 'no' to sex. Consent should be actively prioritised for all involved. Societal leadership has to think about educating the next generation about the problems embedded in rape culture. As noted by Chitando (2007), families may start with disrupting gender stereotyping by decolonising the boy-child mentality that they are superior to the girl child. The masculinity of the boy child should be toned down by teaching the boy child to appreciate notions of feminism. If kinship notions are appropriately addressed, as the children grow up, especially the girl child, they will be rest assured that the family provides them with a safe and secure space, which offers them a sanctuary from the preying and marauding eyes (Chitando \& Chirongoma 2008). Hence, constantly entrenching the ideals enshrined in the principles of ukama whereby the safety, health and well-being of the other is a mutual and communal responsibility will serve as a deterrent against sexual and gender-based violence, particularly rape culture.

\section{Hunhuism (humanness or human kindness)}

Hunhuism is central to people's behaviour and attitudes within the Shona indigenous religion and culture (Murove 2009). There is a need for revising some elements of the Shona indigenous practices promoting rape culture. For instance, it is slowly becoming clear that the practice of roora must either be removed or revisited. Because of the oppressive problems posed to women by the practice of roora, Togarasei (2020) called for abolishing the custom. Instead of focusing on roora, the Shona indigenous religion and culture should concentrate on hunhuism as a base of building marriages. Hunhu strives on building relational personhood, which improves how husbands perceive their wives. The western token of marriage where there is no roora payment can be adopted, and the token of appreciation can become an affordable ring, which the man will give to his wife. Our proposition of this shift in the roora tradition avers with Taringa and Museka (2020) who reiterated that roora should be treated like a ceremonial practice than a commercial transaction, which is now gaining prominence because of misappropriation and misinterpretation that has been wrought by the dilution of the practice because of foreign and external cultures and practices. In the light of this background, this article proposes 
that laws should be enforced that address property ownership, marriage, divorce and child custody whenever one is convicted of sexually assaulting women. For one to be considered munhu [human being], there should be qualities promoting harmony (Sande 2021). Therefore, in order to reduce rape culture, perpetrators of sexual violence must be prosecuted with a stiffer penalty.

Statistics on violence against women are shocking; therefore, victims of rape culture must receive justice. Like the woman in the parable told by Jesus in Luke 18:1-8, African women should refuse to be silenced, they must continue to crying out '[g]rant me justice!' (Dube 2004:3). Since time immemorial, African women have been struggling to breathe under the banner of patriarchy. Their muffled voices have finally found an outlet through ecumenical networks, such as the Circle of Concerned African Women Theologians (the Circle). African women theologians have tenaciously applied cultural hermeneutics to interrogate death-dealing and life-denying practices, such as rape culture. As noted by Kanyoro (2002):

[C]ultural hermeneutics is an important first step towards an African women's theology. All questions regarding the welfare and status of women in Africa are explained within the framework of culture ... However, it is not enough simply to analyse culture without reference to the people who maintain the culture and on whom culture impacts. Here is where the need arises for a gender-sensitive cultural hermeneutics because it doubles in addressing issues of culture while being critical of that culture from a gender perspective. (p. 18)

Thus, African women theologians are raising a clarion call for fellow African women to interpret culture with hermeneutics of suspicion. For instance, Chisale (2018:6) argued that 'women are guilty of internalising oppressive socialisations. Women tend to protect some of the oppressive teachings of culture and tradition'. Likewise, Kamaara and Wangila (2009:131) asserted that 'women are not only victims but also perpetrators of oppression against themselves'. It is in response to such internalised oppressions that have been endured by African women for far too long that Dube (2004), whilst writing within the context of the gendered nature of the HIV epidemic engages in a feminist re-reading of Luke 18:1-8, makes the following comments, which speak eloquently to the need for African women to demand justice in the face of rape culture:

$[W]$ hen one reads the story through, one is struck that persistent prayer is equated with action-oriented search for justice. Persistent prayer is not a passive and private affair that we do behind our closed doors, nor is it tolerant of injustice. Rather, persistent prayer is a luta continua (the struggle continues) act of insisting and working for the establishment of justice. Persistent prayer is, therefore, the refusal to live in oppression and exploitation until justice is established. Moreover, the parable ends with a big theological bang when it underlines, with no uncertain terms, that God is a God of justice, a God who grants justice to the marginalized and oppressed. Moreover, this God grants justice to the oppressed in time, for justice delayed is justice denied. (pp. 3-4)
Hence, in a similar fashion with the persistent widow, African women should continue to press for justice when cultural traditions trample upon their humanity and dignity. They should reclaim their humanity and dignity armed with the knowledge that rape culture dehumanises both the perpetrators and the victims of rape.

\section{Sanctity of life}

Rape culture disregards the concept of sanctity of life. Valuing the sanctity of life is an everyday opportunity to examine behaviours that permit rape culture. Life is a gift of God, and thus, no one has the right to abuse or violate another individual. Therefore, a person is not alone and should consider themselves as part of others. Therefore, valuing the sanctity of life helps people not to discuss cases of sexual violence by focusing on the victim's sobriety or dressing; however men and boys should desist from sex as an entitlement because they are masculine. Men should redefine the meaning of masculinity with the lenses of the sanctity of life and feminist principles. It is high time that hegemonic masculinity be replaced with redemptive masculinities (Chitando \& Chirongoma 2012). Community leaders should make a commitment and begin in earnest to implement policies and practices that will completely eradicate sexual violence and harassment. Proactive social justice for victims of sexual violence is not blaming them for what they should have performed but assuring them that their lives matter. Whilst the rule of law is taking its course, communities should empathise with them using affirmative words, such as 'we hear, see, and believe you'. Victims' stories and experiences deserve to be heard and, more importantly, they deserve empathy and justice.

Writing within the context of respecting and valuing all human lives during the peak of the HIV epidemic in Africa, the following views raised by Dube (2006) strike a melodious chord when it comes to interrogating rape culture within indigenous Africa communities:

An approach based on Setho/Ubuntu would also question a culture that defines women and children as powerless subordinates, thus exposing them to HIV infection [read 'rape culture']. Recapturing batho as 'a process of earning respect by first giving it, and [of] gaining empowerment by empowering others,' would be applied to all problematic relationships. Indeed, all socially unhealthy relationships that do not empower or respect some members of the society would be revisited. In other words, the concept of community, the adinkira paradigm, ought to and should become the cornerstone of propounding an African indigenous theology of justice and liberation by constantly revisiting 'what it means to be community and to live in community,' 'what violates community,' and 'how we live in community in our new and hybrid twenty-first century context'. (p. 141)

The points raised in the above-mentioned excerpt ring true to the experiences of the countless African women and girls whose lives have been shattered by the violations of rape. Being in relationship should entail respecting the sexual and reproductive lives of the others. This should entail 
saying no to sexual and gender-based violence in all areas of our lives. As such, African men and women should work together towards insulating their homes, workplaces, faith communities, and all communal spaces of sexual and genderbased violence, particularly the crime of rape. The following pointers suggested by Dube (2006) poignantly beckons us to this worthwhile cause:

Being in community is not and cannot be a one-time thing; rather it is a process that must be continually cultivated by its members. This approach should inform the continual assessment and review of oppressive relationships and the reimagination of communities that respect and empower all their members regardless of class, gender, age, ethnicity, race, sexuality, and nationality for it is only then that we can say 'I am because we are, and we are because I am'. The adinkira space of justice, solidarity, and liberation in African cosmology is highly relevant and central to the struggle against HIV \& AIDS [read 'rape culture'], but work must be done to implement it. As clearly expounded in the above excerpt, African indigenous communities are well known for respecting human lives as a sacred gift. The sacredness of life should therefore influence the manner in which men and women interact in sexual relations. If all human lives are sacred, there will be no basis for violating another human being sexually, not even bestiality would be acceptable in such a worldview. (p. 141)

\section{Conclusion}

Rape culture is found to be prevalent in sub-Saharan Africa, and it continues to be sustained through culture, patriarchy, poverty and religion. Focusing particularly on the Shona indigenous culture, this study conceptualised rape culture as the normalisation of sexual violence and blaming the victims for the assaults. Rape culture broadly entails the societal norms and values that trivialise acts of sexual violation, silencing, blaming, and intimidating sufferers and survivors whilst protecting and justifying the perpetrators of sexual and gender-based violence. Using the African feminist lenses, particularly the African cultural hermeneutical framework, this study showed that the relationship between men and women should be viewed as a relational ontology. It foregrounded the problem that this relational ontology is not balanced. For instance, several practices within the Shona indigenous religion and culture are a laboratory for constructing rape culture. These patriarchal norms and values are blamed for fostering abuse, coercion and control of women. As demonstrated in this study, some marital practices are responsible for the objectification of women's bodies. Women's bodies are objectified as elements of sex, thereby constructing rape culture. The solutions suggested for eradicating rape culture were framed to understand that rape culture is an intersectional reality. Therefore, solutions are far more than merely reducing the frequency with which sexual abuse occurs or the latitude that permits it. This study recommends that the solution for rape culture should magnify kinship, hunhuism and sanctity of life as tools that can help to stand against rape culture.

\section{Acknowledgements Competing interests}

The authors declare that they have no financial or personal relationships that may have inappropriately influenced them in writing this article.

\section{Authors' contributions}

Both authors contributed equally to writing of the article.

\section{Ethical considerations}

This article followed all ethical standards for research without any direct contact with human or animal subjects.

\section{Funding information}

This research received no specific grant from any funding agency in the public, commercial or not-for-profit sectors.

\section{Data availability}

Data sharing is not applicable to this article as no new data were created or analysed in this study.

\section{Disclaimer}

The views and opinions expressed in this article are those of the authors and do not necessarily reflect the official policy or position of any affiliated agency of the authors.

\section{References}

Ackermann, D.M., 2004, 'Tamar's cry: Re-reading an ancient text in the midst of an HIV and AIDS pandemic', in M.W. Dube \& M. Kanyoro (eds.), Grant me justice! HIV/ AIDS \& gender readings of the Bible, pp. 28-59, Cluster Publications, Pietermaritzburg.

Adeniyi, E., 2021, 'Penis primacy, female marginality, and masculine subjectivity in "Nigeria's Rape Culture"', Quarterly Review of Film and Video. https://doi.org/10. 1080/10509208.2021.1926890

Ademiluka, S.O., 2018, 'Patriarchy and women abuse: Perspectives from ancient Israel and Africa', OTE 31(2), 339-362.

Ahikire, J., 2014, African feminism in context: Reflections on the legitimation battles, victories and reversals, 29 April 2021, from http://www.agi.ac.za/sites/default/ victories and reversals, 29 April 2021, from http://www.agi.ac.za/sites/default/
files/image_tool/images/429/feminist_africa_journals/archive/02/features_files/image_tool/images/429/feminist_africa_journals/archive/02/features_-_african_feminism_in_the_21st_cen_th.
victories_battles_and_reversals.pdf.

Arnfred, S. (ed.), 2004, Re-thinking sexualities in Africa, Almqvist \& Wiksell Tryckeri $A B$, Sweden.

Bayu, E.K., 2019, 'A comparative analysis on the perspectives of African Feminism Vs Western Feminism: philosophical debate with their criticism and its implication for women's rights in Ethiopia context', International Journal of Sociology and Anthropology 11(4), 54-58. https://doi.org/10.5897/IJSA2018.0783

Beyers, J., 2017, 'Religion and culture: Revisiting and close relative', HTS Teologiese Studies/Theological Studies 73(1), a3864. https://doi.org/10.4102/hts.v73i1.3864

Brown, E.N., 2014, Against sexual autonomy: Why sex law's Lodestar should beselfpossession, viewed 28 February 2021, from https://www.libertarianism.org/ columns/against-sexual-autonomy-why-sex-lawslodestar-should-be-selfpossession.

Brown, S., 2018, 'Rape culture or a culture of rape? American rape culture compared to South African rape accommodating culture', unpublished Senior Honors thesis submitted in Partial Fulfillment of the Requirements for Graduation in Political Science, Criminal Justice, and International Studies Majors, The College at Brockport, New York, NY.

Brownmiller, S., 1975, Against our will: Men, women and rape, Simon and Schuster, New York, NY.

Buchwald, E., Fletcher, P. \& Roth, M., 1994, Transforming a rape culture, Milkweed Editions, Minneapolis, MN.

Buchwald, E., Fletcher, P.R. \& Roth, M. (eds.), 2005, Transforming a rape culture, rev. edn., Milkweed Editions, Minneapolis, MN. 
Burnett, A., Mattern, J.L., Herakova, LL., Kahl, Jr. D.H., Tobola, C. \& Bornsen, S.E., 2009, 'Communicating/muting date rape: A co-cultural theoretical analysis of communication factors related to rape culture on a college campus', of communication factors related to rape culture on a college campus,
Journal of Applied Communication Research 37(4), 465-485. https://doi. org/10.1080/00909880903233150

Burt, M.R., 1980, 'Cultural myths and supports for rape', Journal of Personality and Social Psychology 38, 217-230. https://doi.org/10.1037/0022-3514.38.2.217

Butler, J., 1993, Bodies that matter: On the discursive limits of 'sex', Routledge, London.

Chigidi, W.L., 2009, 'Moral dimensions of some Shona Taboos (Zviera)', The Journal of Pan African Studies 3(1), 174-187.

Chingombe, A., Mandova, E. \& Nenji, S., 2012, 'Perception and management of human fertility: A Shona landscape', International Journal of Management and Sustainability 1(1), 1-12.

Chireshe, E., 2015, 'Barriers to the utilisation of provisions of the Zimbabwean Domestic Violence Act among abused Christian women in Zimbabwe', Journal of Domestic Violence Act among abused Christia
International Women's Studies 16(2), 259-273.

Chirongoma, S., 2006, 'Women's and children's rights in the time of HIV and AIDS in Zimbabwe: An analysis of gender inequalities and its impact on people's health', Journal of Theology for Southern Africa 2(126), 48-65.

Chirongoma, S., 2016, 'African women's voices on sexual and reproductive health rights, and sexual gender-based violence', in E. Chitando \& N. Njoroge (eds.), Abundant life: The churches and sexuality, pp. 91-107, World Council of Churches Publications, Geneva.

Chiroro, P., Bohner, G., Viki, G.T. \& Jarvis, C.I., 2004, 'Rape myth acceptance and rape proclivity: Expected dominance versus expected arousal as mediators in acquaintance rape situations', Journal of Interpersonal Violence 19, 1-16. https:// doi.org/10.1177/0886260503262081

Chisale, S.S., 2018, 'Ubuntu as care: Deconstructing the gendered Ubuntu', Verbum et Ecclesia 39(1), a1790. https://doi.org/10.4102/ve.v39i1.1790

Chitando, E., 2007, 'A new man for a new era? Zimbabwean pentecostalism, masculinities, and the HIV epidemic', Missionalia 35(3), 112-127.

Chitando, E., 2008, 'Religious ethics, HIV and AIDS and masculinities in Southern Africa', in R. Nicolson (ed.), Persons in community: African ethics in a global culture, pp. 5-28, University of KwaZulu-Natal Press, Pietermaritzburg.

Chitando, E., 2015, “"Do not tell the person carrying that s/he stinks": Reflections in Ubuntu and masculinities in the context of sexual and gender-based violence and HIV', in E. Mouton, G. Kapuma, L. Hansen \& T. Togom (eds.), Living with dignity: African perspectives on gender equality, pp. 269-283, Sun Press, Stellenbosch.

Chitando, E. \& Chirongoma, S., 2008, 'Challenging masculinities: Religious studies, men and HIV in Africa', Journal of Constructive Theology 14(1), 55-69.

Chitando, E. \& Chirongoma, S., 2012, Redemptive masculinities: Men, HIV, and religion, pp. 1-11, World Council of Churches, Zapf Chancery Publishers Africa, Nairobi.

Chiweshe, M.K., 2016, 'Wives at the market place: Commercialization of Lobola and commodification of women's bodies in Zimbabwe', The Oriental Anthropologist $A$ Bi-annual International Journal of the Science of Man 16(2), 229-243. https://doi. org/10.1177/0976343020160202

Crenshaw, K., 1991, 'Mapping the margins: Intersectionality, identity politics, and violence against women of color', Stanford Law Review 43(6), 1241-1299. https:// doi.org/10.2307/1229039

Doan-Minh, S., 2019, 'Corrective rape: An extreme manifestation of discrimination and the state's complicity in sexual violence', Hastings Women's Law Journal 30, 167.

Dube, M.W., 2004, 'Grant me justice: Towards gender-sensitive multi-sectoral readings HIV readings of the Bible', in M.W. Dube \& M. Kanyoro (eds.), Grant me justice. HIV/AIDS \& gender readings of the Bible, pp. 3-26, Cluster Publications, Pietermaritzburg.

Dube, M.W., 2006, 'Adinkira! Four hearts joined together: On becoming healingteachers of African indigenous religion/s in HIV \& AIDS prevention', in I.A. Phiri \& S. Nadar (eds.), Women, religion and health: Essays in honour of Mercy Amba Ewudziwa Oduyoye, pp. 131-156, Orbis Books: Maryknoll, New York, NY.

Fakunmoju, S.B., Abrefa-Gyan, T., Maphosa, N. \& Gutura, P., 2021, 'Rape myth acceptance: Gender and cross-national comparisons across the United States, South Africa, Ghana, and Nigeria', Sexuality \& Culture 25, 18-38. https://doi. org/10.1007/s12119-020-09755-z

Herman, D.F., 1984, 'The rape culture', in J. Freeman (ed.), Women: A feminist perspective, 3d edn., pp. 45-53, Mayfield, Mountain View, CA.

Jewkes, R., Fulu, E., Roselli, T. \& Garcia-Moreno, C., 2013, 'Prevalence of and factors associated with non-partner rape perpetration: Findings from the UN multi-country cross-sectional study on men and violence in Asia and the Pacific', The Lancet Global Health 1, 208-218. https://doi.org/10.1016/S2214 109X(13)70069-X

Kamaara, E. \& Wangila, M.N., 2009, 'Contextual theology and gender reconstructions in Kenya', Theologies and Cultures VI(2), 110-133.

Kambarami, M., 2000, Femininity, sexuality and culture; Patriarchy and female subordination in Zimbabwe, University of Fort Hare, Alice.

Kanyoro, M., 2002, Introducing feminist cultural hermeneutics: An African perspective, Sheffield Academic Press, Sheffield.

Khau, M., 2007, “'But he is my husband! How can that be rape?": Exploring silences around date and marital rape in Lesotho', Agenda 21(74), 58-66. https://doi.org/ 10.1080/10130950.2007.9674876

Kivel, P., 2012, 'The act-like-a-man box', in M. Kimmel \& M. Messner (eds.), Men's lives, 9th edn., pp. 14-16, Pearson Education, Boston, MA
Lonsway, K.A. \& Fitzgerald, L.F., 1994, 'Rape myths: In review', Psychology of Women Quarterly 18, 133-164. https://doi.org/10.1111/j.1471-6402.1994.tb00448.x

Madden, K., 2014, Rape culture: The media's role in normalizing assault, viewed 24 June 2021, from http://laverne.edu/campus-times/2014/05/rape-culture-themedias-role-in-normalizing-assault/.

Manyonganise, M., 2015, 'Oppressive and liberative: A Zimbabwean women's reflections on Úbuntu', Verbum et Ecclesia 36(2), 1-7. https://doi.org/10.4102/ ve.v36i2.1438

Maxwell, Z., 2014, Rape culture is everywhere our children can see - Watch your favorite movies prove it, viewed 18 February 2021, from http://mic.com/ articles/94844/rape-culture-is-everywhere-our-children-can-see-watch-yourfavorite-movies-prove-it.

Mbiti, J.S., 1970, African religions and philosophy, Anchor, Garden City, NY

Moradi, B. \& Huang, Y., 2008, 'Objectification theory and psychology of women: A decade of advances and future directions', Psychology of Women Quarterly 32 277-398.

Muguti, M. \& Sande, N., 2019, 'Women's sexualized bodies: Dealing with women's sexual autonomy in pentecostalism in Zimbabwe', in J. Kugler, R. Gabaitse \& J. Stiebert (eds.), Gender and troubles in Africa, pp. 185-202, University of J. Stiebert (eds.), Gender
Bamberg Press, Bamberg.

Mungwini, P. \& Matereke, K., 2010, 'Rape, sexual politics and the construction of manhood among the Shona of Zimbabwe: Some philosophical reflections thought and practice', A Journal of the Philosophical Association of Kenya (PAK) New Series 2(1), 1-19. https://doi.org/10.4314/tp.v2i1.57662

Murove, M.F., 2007, 'The Shona ethic of Ukama with reference to the immortality of values', Mankind Quarterly 48(2), 179-189. https://doi.org/10.46469/mq.2007.48.2.4

Murove, M.F., 2009, 'An African environmental ethic based on the concepts of Ukama and Ubuntu', in M.F. Murove (ed.), African ethics: An anthology of comparative and applied ethics, pp. 315-331, University of KwaZulu-Natal Press, Pietermaritzburg.

Nadar, S., 2006, "Texts of terror" The conspiracy of rape in the Bible, Church and Society: The case of Esther $2: 1-18^{\prime}$, in I.A. Phiri \& S. Nadar (eds.), Women, religion and health: Essays in honour of Mercy Amba Ewudziwa Oduyoye, pp. 77-89, Orbis Books: Maryknoll, New York, NY.

Najumi, M., 2013, We live in a rape culture, viewed 20 February 2021, from http:// thefeministwire.com/2013/06/we-live-in-a-rape-culture/.

Ndemanu, M.T., 2018, 'Traditional African religions and their influences on the worldviews of Bangwa people of Cameroon: Expanding the cultural horizons of study abroad students and professionals', Frontiers: The Interdisciplinary Journa of Study Abroad XXX(1), 70-84. https://doi.org/10.36366/frontiers.v30i1.405

Ngubane-Mokiwa, S.A. \& Chisale, S.S., 2019, 'Male rape or consensual sex: Hidden hegemonic masculinities by Zulu speaking men with disabilities', Ubuntu:
Journal of Conflict and Social Transformation 8(2), 107-124. https://doi. org/10.31920/2050-4950/2019/SIn2a6

Oduyoye, M.A., 2004, Beads and strands: Reflections of an African woman on Christianity in Africa Orbis Books, Maryknoll, New York, NY.

Olupona, J., 2007, Beyond primitivism, Routledge, New York, NY.

Owomoyela, O., 2002, Culture and customs of Zimbabwe, Greenhood Press, London.

Oyekan, A.O., 2014, 'African feminism: Some critical considerations', Philosophia (Philippines) 15(1), 1-10.

Perrin, N., Marsh, M., Clough, A., Desgroppes, A., Phanuel, C.Y., Abdi, A. et al., 2019 'Social norms and beliefs about gender based violence scale: A measure for use with gender based violence prevention programs in low-resource and humanitarian settings', Conflict and Health 13, 6. https://doi.org/10.1186/s13031-019-0189-x

Petrus, T.S., 2017, 'The myth of "rape culture": A critique of feminist distoortions of the culture concept in the gender war in South Africa, and their implications for development', Journal of Social Development in Africa 32(2), 1-10.

Ridgway, S., 2014, 25 everyday examples of rape culture, viewed 23 February 2021 from http://everydayfeminism.com/2014/03/examples-of-rape-culture/.

Sande, N., 2017, 'Faith and equality: Rethinking women in leadership positions in pentecostalism', Journal of Gender and Religion in Africa 23(1), 50-62.

Sande, N., 2021, 'The impact of technologies on African Religions: A theological perspective', in B. Okyere-Manu (ed.), African values, ethics, and technology, pp. 247-261, Springer, New York, NY.

Sande, N. \& Takawira-Matwaya, forthcoming, 'Assisted reproductive technologies, infertility and women in Zimbabwe', in S. Chirongoma, M. Manyonganise \& E. Chitando (eds.), Zimbabwe at forty: Religio-cultural perspectives impacting on women's sexual reproductive health and rights.

Tamale, S., 2013, 'Exploring the contours of African sexualities: Statutory, customary and religious laws', paper presented at the conference on 'Law and Religion in Africa: Comparative Practices, Experiences and Prospects' held at the University of Ghana, Accra, 14-15th January.

Taringa, N.T. \& Museka, G., 2020, 'No to bride price/bride wealth, yes to Roora: Investigating the meaning, function and purpose of Roora as a ritual', in L. Togarasei \& E. Chitando (eds.), Lobola (Bridewealth) in contemporary Southern Africa, pp. 13-27, Palgrave Macmillan, Cham.

Thompson, B., 2008, Black womanhood: Images, icons and ideologies of the African beauty, Washington Press, Seattle, WA.

Togarasei, L., 2012, 'Pauline challenge to African masculinities', Acta Theologica Supplementum 16, 148-160.

UN Women, 2019, 16 ways you can stand against the rape culture, viewed 10 February 2021, from https://lac.unwomen.org/en/noticias-y-eventos/articulos/ 2019/11/compilation-ways-you-can-stand-against-rape-culture.

Wood, J.T., 1994, 'Gendered media: The influence of media on views of gender', in Gendered lives: Communication, gender, and culture, pp. 231-244, Wadsworths Publishers, Boston, MA. 